\title{
Marian Chace Foundation Lecture: Introduction to Dr. Robyn Flaum Cruz
}

\author{
Miriam Roskin Berger ${ }^{1}$
}

Published online: 5 March 2018

(C) American Dance Therapy Association 2018

It is my honor and my privilege and my deep pleasure to introduce Dr. Robyn Cruz, the 2017 Marian Chace Foundation Lecturer. For the past 38 years, Robyn's vast achievements in dance/movement therapy have been incredible, and her contributions to our field have been, I am certain, one of the critical reasons for its steady growth. Her achievements include innovative clinical work, distinguished academic appointments, crucial research in many areas, countless publications, 13 years of being editor-inchief of The Arts in Psychotherapy, and leadership of the ADTA as Vice-President and President, and co-editor of the American Journal of Dance Therapy.

I first met Robyn when she entered the NYU Masters' program in 1979, after she completed her Bachelors' degree at Vanderbilt University in her home state of Tennessee. (And I must mention that I believe this is the first time a teacher has introduced her student as the Chace Foundation Lecturer). You can well imagine how proud I am, and how gratifying this privilege is to me. One of the gifts of being an educator is the pleasure one gets from witnessing the continual accomplishments of one's students. The deeper pleasure is that you get to see your students achieve the things you dreamt of doing yourself when you began your career. It is hard to find the exact words to express this, but Robyn has done everything I wished I had done. I have taught hundreds, maybe even thousands of students over the years, here in the United States and abroad, and I clearly remember many of them. But I must say in all candor that Robyn is the only one who I remember from the first moment I met her when she entered NYU. I cannot say exactly what left such a strong impression. I only know that I somehow sensed immediately that she was uniquethat she was special. I wish I could claim that my teaching had a great effect on her future accomplishments, but in truth I think she herself embodied that future in her 1979 self.

Miriam Roskin Berger

Mb33@nyu.edu

1 New York University, New York, NY, USA 
Robyn completed her internship in my Creative Arts Therapy department at Bronx Psychiatric Center and, after her NYU graduation in 1981, I immediately hired her as part of our dance/movement therapy staff where she worked until 1988. She did everything: she worked with adult inpatients and outpatients individually and in groups; she was part of interdisciplinary treatment team on residency training unit affiliated with Albert Einstein College of Medicine; she ran staff-in-training, including graduate dance/movement therapy interns. And she had administrative duties supervising a rehabilitation program.

I was her supervisor, of course (and I must confess that our supervisory sessions ultimately consisted mainly of quick drives from the Bronx to Westchester to shop for clothes in the Bonwit Teller outlet as we have always shared a deep interest in style!) She then began to teach at NYU and to supervise graduate dance/movement therapy interns. And, somehow, during that time between 1981 and 1988, Robyn also managed to teach a dance/movement therapy course at the New School for Social Research. This was the beginning of her remarkable career of multi-tasking on a very grand scale.

In 1989 Robyn left the East to conquer the South West. First in New Mexico, where she was Clinical Supervisor with Adolescent Shelter bed, Behavioral Health Services Division at Rehoboth McKinley Christian Hospital in Gallup. There she trained and supervised a staff of 12 para-professional youth care workers in treatment issues for adjudicated adolescents, adolescents with substance abuse, sexual abuse, and physical abuse histories and also delivered direct services to adolescents and families. And later on to Tucson, Arizona where she was Adjunct Faculty at Pima Community College, Human Sciences Division; Outpatient Psychotherapist, Las Familias; Consultant, Statistics and Research Methods, at the University of Arizona, in the Departments of Library Sciences, Psychology, Educational Psychology, Speech and Hearing Sciences; Research Specialist, Principal, National Center for Neurogenic Communication Disorders, The University of Arizona; Adjunct Assistant Professor, The University of Arizona, Department of Educational Psychology where she taught statistics and research courses to Ph.D. students from various disciplines; and Director of Research, Cope Behavioral Services, Inc., Tucson, from 1999 to 2002.

Robyn squeezed in a few other academic appointments in the east when she taught research courses at New York University and Pratt Institute from 1997 to 2002. And worked once again with me in the Netherlands at the Rotterdam Dansacademie Program in Dance Therapy, teaching research and dance/movement therapy. Then back east to Pittsburgh as the Director of Creative and Expressive Arts Therapies, Western Psychiatric Institute \& Clinic, University of Pittsburgh Medical Center from 2002 to 2005 where, among other responsibilities, she developed new initiatives for inpatient service delivery and expansion of Creative and Expressive Arts Therapies. And then, on to Boston and Lesley University where she became Associate Professor and Coordinator for Dance Therapy, Division of Expressive Therapies from 2005 to 2008 and then Professor, Expressive Therapies Ph.D. Program, 2008 to the present where she is cohort advisor and instructor for $\mathrm{Ph}$.D. students and courses and where she has developed course curricula for low residency model delivery including use of web technology. During this time, Robyn 
advised and consulted at other universities, did many presentations around the world, including the World Congress of Psychiatry in Cairo Egypt in 2005, and taught the Movement Psychiatric Inventory with Martha Davis and me in Amsterdam and Berlin.

Robyn now serves on the Advisory Boards of the University of California Los Angeles, UCLA Arts and Healing; the North American Journal of Drama Therapy; Expressive Media Incorporated; and the Andrea Rizzo Foundation. Her many awards include:

Alice K. Ladas award for Outstanding Research in Somatic Psychology (2016) United States Association for Body Psychotherapy; President's Award (2014) American Dance Therapy Association; Research Fellowship (2007-2008), Center for Research Fellowship Program, Graduate School of Arts and Social Sciences, Lesley University; Grant recipient, Marian Chace Foundation of the American Dance Therapy Association (2003); Who's Who in America (2003-2006); Graduate Registration Scholarship, University of Arizona (1992-1993).

So....Dr. Cruz's clinical work has spanned populations such as adults with serious and persistent mental illnesses and children and adolescents with trauma and substance abuse issues. Her doctoral degree is in Educational Psychology with a specialization in Measurement and Methodology. She has worked as a research methodologist, research consultant, and statistician. She has enjoyed teaching doctoral students since 1995, and has taught graduate courses in dance/movement therapy, research methods, and statistics to students from many different disciplines in the US, Europe, and South America.

She is co-author of two textbooks: Dance/Movement Therapists in Action: A Working Guide to Research Options and Feders' Art and Science of Evaluation in the Arts Therapies. In addition, she has authored over 50 articles in refereed journals across the disciplines of dance/movement therapy, psychiatry, psychology, neurology, and communications disorders. Robyn loves research and has been a member of the ADTA Research Subcommittee since 1994, and her current research interests include: expanding the evidence-base for dance/movement therapy; enhancing diagnostic specificity using movement assessments; movement disorders; applying research to clinical practice; and using research to advocate for the arts therapies as viable healthcare professions that bring humanity to caring for those in need. I think her explorations in research are what are most gratifying to me as that it is the one area in which I was deeply interested but never pursued. And I believe it is her research explorations that will validate our discipline and propel this discipline ever onward.

I have really just touched on all that Robyn has done and given you examples of her extraordinary achievements. I truly sat almost helpless as I looked at her CV.... The list of what she has done is endless and, even though Robyn now seems to have cut back a little, the list goes on. How is it possible for one person to have achieved and created so much? What qualities does Robyn possess that have enabled this remarkable career?

Robyn, of course, is incredibly intelligent. Just as importantly, she has the capacity to understand and integrate many disparate areas of inquiry and knowledge from the aesthetics of dance to theories of human movement to three- 
dimensional statistical analysis. And she has the rare ability to be able to convey her knowledge to others. She also has deep qualities of empathy and compassion and a stable perspective on the world. And, always, she has a positive and optimistic attitude in relation to human existence and human problems. One can feel the warmth and optimism of her spirit emanating through all she does. Not often does one find this combination of steely intelligence and emotional openness. Robyn possesses this as well as a depth of many other talents.

As I said at the start, it is a unique experience for a teacher to be able to introduce such a distinguished student - a student who is now a distinguished colleague and my close friend; a student who has now surpassed all of her teachers in her lifetime to become a unique force in her own right. I am deeply gratified that Robyn has achieved what I dreamt of achieving, and in admiration of these achievements and her special qualities I proudly present to you the 2017 Marian Chace Lecturer, Dr. Robyn Cruz.

Funding This introduction was not grant funded.

\section{Compliance with Ethical Standards}

Conflict of interest I, Dr. Miriam Roskin Berger, declare that I have no conflict of interest.

Ethical Approval This article does not contain any studies with human participants or animals performed by any of the authors.

\section{Dr. Miriam Roskin Berger}

BC-DMT, LCAT, An early pioneer of dance/movement therapy while she performed with the Jean Erdman Theatre of Dance, Dr. Berger teaches dance/movement therapy at New York University, where she was the Director of the Program in Dance Education from 1993 to 2002. She is also currently the Director of the Dance Therapy Program at the Harkness Dance Center of the 92nd Street Y. and at the National Dance Therapy Centre of Les Grands Ballets Montreal de Canadiens, She has created dance/movement therapy training programs in the Czech Republic, the Netherlands, and Sweden, and has taught dance/movement therapy and the Movement Psychodiagnostic Inventory in France, Germany, Greece, Korea, Norway, Poland, Russia, Slovenia, Spain and Taiwan. She initiated the International Panel of the ADTA in 1995. In 2009, Dr. Berger received the Charles Kellogg Award in Arts and Letters from Bard College, the ADTA Lifetime Achievement Award in 2007, was inducted into the Dance Library of Israel Hall of Fame in 2005, and she was given the Marian Chace Award for fostering the international growth of dance/movement therapy in 2002. Past President and charter member of the American Dance Therapy Association, Dr. Berger was Director of the Creative Arts Therapies Dept. at Bronx Psychiatric Center 1970-1990, and is a past Chair of the National Coalition of Creative Arts Therapies. A former coeditor, of the American Journal of Dance Therapy and editorial board member of the Journal of Dance Education, she now is on the board of Arts in Psychotherapy and the American Journal of Dance Therapy. An early student of dance/movement therapy pioneers Marian Chace, Irmgaard Bartenieff, and Rhoda Winter Russell, Dr. Berger studied non-verbal communication with Albert Scheflen, Martha Davis, Marion North, Judith Kestenberg and Warren Lamb. 